\title{
Importance of shallow-water biotopes of a Caribbean bay for juvenile coral reef fishes: patterns in biotope association, community structure and spatial distribution
}

\author{
I. Nagelkerken ${ }^{1,2}$, M. Dorenbosch ${ }^{2}$, W. C. E. P. Verberk ${ }^{2}$, \\ E. Cocheret de la Morinière ${ }^{2}$, G. van der Velde ${ }^{2, *}$ \\ ${ }^{1}$ Carmabi Foundation, PO Box 2090, Piscaderabaai z/n, Curaçao, Netherlands Antilles \\ ${ }^{2}$ Laboratory of Aquatic Ecology, Aquatic Animal Ecology Section, University of Nijmegen, Toernooiveld 1, \\ 6525 ED Nijmegen, The Netherlands
}

\begin{abstract}
Fish community structure of a non-estuarine inland bay on the Caribbean island of Curaçao was determined in the mangroves, seagrass beds, algal beds, channel, fossil reef boulders, notches in fossil reef rock, and on the adjacent coral reef, using visual censuses in belt transects. Fish communities varied among biotopes, but some overlap was present. Fish density and species richness were highest at the boulders and on the coral reef, and extremely low on the algal beds, whereas the total number of individuals calculated for the entire bay was highest on the seagrass beds. Differences in fish densities between biotopes were related to differences in structural complexity and amount of shelter. Fishes in the bay largely consisted of 17 (mainly commercially important) reef fish species, which used the bay biotopes only as a nursery during the juvenile part of their life cycle. Small juveniles of these species were most often found in the mangroves, whereas at intermediate sizes some were found in the channel. Large individuals and adults were found on the reef, and densities of several of these species were higher on the reef near the bay than on reefs located farther down-current. Fishes which spent their entire life cycles in either the bay or on the coral reef were also found, and the latter group showed a strong decrease in abundance with increasing distance into the bay. The density distribution of individual fish species was not homogeneous within the bay. In the mangroves and seagrass beds, spatial distribution of fishes was correlated with distance to the mouth of the bay, water transparency, amount of shelter, and the structural complexity of the biotope. Juveniles of 3 reef species showed an increase in size on the seagrass beds with distance from the mouth into the bay, whereas 1 bay species showed a decrease in size with this distance.
\end{abstract}

KEY WORDS: Mangroves $\cdot$ Seagrass beds $\cdot$ Coral reef fish $\cdot$ Nursery $\cdot$ Habitat association $\cdot$ Community structure $\cdot$ Habitat complexity

\section{INTRODUCTION}

Considerable knowledge has been gained about the importance of tropical and temperate estuaries and lagoons for fishes. Tropical estuaries or lagoons may contain freshwater, estuarine-dependent, coral reef, as well as pelagic fishes. Many estuaries and lagoons in

*Corresponding author. E-mail: gerardv@sci.kun.nl the Caribbean, Indian Ocean and the Pacific Ocean function as nurseries for juvenile fish (Pollard 1984, Parrish 1989, Robertson \& Blaber 1992). In the tropical western Atlantic, most studies on fish communities focussed on estuaries or lagoons on mainland coasts (e.g. Springer \& McErlean 1962, Perret \& Caillouet 1974, Weinstein \& Heck 1979, Sogard et al. 1987, Thayer et al. 1987, Yáñez-Arancibia 1988, Rozas \& Minello 1998). Less attention has been paid to estuaries and lagoons 
on island locations (Robblee \& Zieman 1984, Stoner 1986, Baelde 1990, Rooker \& Dennis 1991). Studies of fish communities on island locations in non-estuarine inland bays are largely lacking (e.g. van der Velde et al. 1992, Nagelkerken et al. 2000b).

Lagoons can contain a variety of biotopes, such as mangroves, seagrass beds, algal beds, areas with bare sediment, channels, sand-rubble zones or patch reefs. The linkages of fishes between these biotopes remain largely unknown (Ogden \& Gladfelter 1983, Parrish 1989), as most studies have focused on single biotopes (e.g. Springer \& McErlean 1962, Weinstein \& Heck 1979, Robblee \& Zieman 1984, Stoner 1986, Sogard et al. 1987). Little information is present on utilisation of multiple nursery biotopes by fishes, and ontogenetic migrations between different biotopes within lagoons. Heald \& Odum (1970) and Rooker \& Dennis (1991) noticed that the mangroves are often used as a habitat for intermediate life-stages by fishes before they move to the coral reef. Only some studies have attempted to compare 2 or more biotopes simultaneously, but often with a different methodology (e.g. Thayer et al. 1987, Acosta 1997). Differences in biotope structure, location of study area, type of lagoon, fishing technique, and observers make comparisons of fish faunas between various biotopes difficult. In-depth studies using a single methodology in a single lagoon on a variety of biotopes are therefore very important (e.g. van der Velde et al. 1992, Sedberry \& Carter 1993, Appeldoorn et al. 1997, Nagelkerken et al. 2000b) to elucidate the roles of different bay biotopes with respect to the nursery function.

Mangroves and seagrass beds have received considerable attention with respect to their nursery function. Several hypotheses have been proposed to explain the high abundance of (juvenile) fishes in these biotopes, based on avoidance of predators, the abundance of food and interception of fish larvae. They include the following: (1) the structural complexity of these biotopes provide excellent shelter against predators (Parrish 1989, Robertson \& Blaber 1992); (2) these biotopes are often located at a distance from the coral reef or from off-shore waters and are therefore less frequented by predators (Shulman 1985, Parrish 1989); (3) the relatively turbid water of the lagoons and estuaries decrease the foraging efficiency of predators (Blaber \& Blaber 1980, Robertson \& Blaber 1992); (4) these biotopes provide a great abundance of food for fishes (Odum \& Heald 1972, Carr \& Adams 1973, Ogden \& Zieman 1977); and (5) these biotopes often cover extensive areas and may intercept planktonic fish larvae more effectively than the coral reef (Parrish 1989).

Structural complexity of mangroves and seagrass beds has been shown to have an effect on the fish abundance and species richness. For the mangroves, the amount of prop-roots, pneumatophores and mangrove debris (e.g. pieces of wood and leaves) are likely to play a role (Robertson \& Blaber 1992). For the seagrass beds, variables such as seagrass biomass and density, and leaf density have been correlated with fish density and species richness (Stoner 1983, Bell \& Westoby 1986, Sogard et al. 1987). When the juvenile fishes outgrow the protection provided by these biotopes, the fishes show an ontogenetic migration to the coral reef or off-shore water (Ogden \& Ehrlich 1977, Weinstein \& Heck 1979, Shulman 1985, Rooker \& Dennis 1991). Most of these ontogenetic migrations have been described qualitatively, and few quantitative studies have been done (e.g. Nagelkerken et al. 2000b).

The present study was carried out in a non-estuarine inland bay on the Caribbean island of Curaçao. To enable comparisons between different bay biotopes a single methodology, visual censuses in belt transects were used to study the abundance, species richness and size structure of fishes in 6 bay biotopes and on the adjacent coral reef.

The objectives of the present study were to answer the following questions: (1) Which fishes are associated with which bay biotopes, and what differences are found in the fish community structure between different bay biotopes? (2) What is the importance of the bay biotopes as a nursery for reef fishes, and what ontogenetic shifts in habitat association are present in these species? (3) Is there a spatial variation in total fish density, species richness, and density and size structure of individual fish species within the bay, and is this spatial variation related to environmental variables, structural complexity of the biotope, and distance to the coral reef?

\section{MATERIALS AND METHODS}

Study area. The present study was carried out in the Spanish Water Bay in Curaçao, Netherlands Antilles (Fig. 1). The mouth of this sheltered bay is situated on the leeward coast near the southeastern end of the island, and is $85 \mathrm{~m}$ wide and protected by a sill with a maximum depth of $6 \mathrm{~m}$. The bay is connected to the sea by a relatively long $(1.1 \mathrm{~km})$ and deep channel which continues into the central part of the bay. Apart from the channel, the bay is relatively shallow (depths $<6 \mathrm{~m}$ ). The average daily tidal range is $30 \mathrm{~cm}$ (de Haan \& Zaneveld 1959). Mean ( \pm SD) water temperature and salinity during the study period (November 1997 through August 1998) at the 12 study sites in the bay were $28.3 \pm$ $0.2^{\circ} \mathrm{C}$ and $35.4 \pm 0.2 \%$, respectively, and on the reef just outside the bay $27.5 \pm 1.2^{\circ} \mathrm{C}$ and $35.0 \pm 0.2 \%$, respectively (see Table 1). The restricted range of salinities demonstrates the oceanic nature of the bay. The bay has 


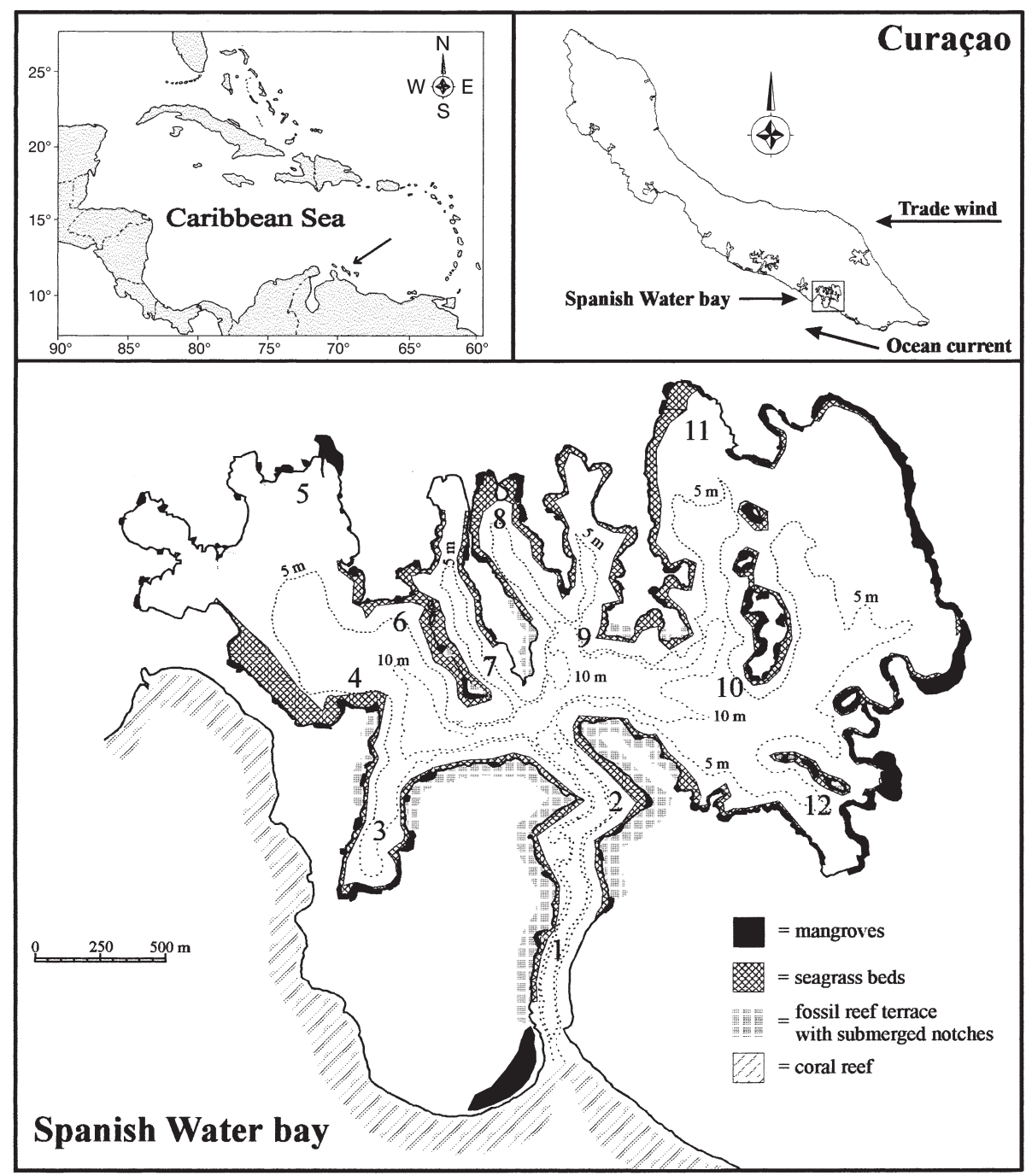

Fig. 1. Map of the Spanish Water Bay showing the location of the study sites (1 to 12). The algal beds generally cover the area between the seagrass beds and the channel (located at the $10 \mathrm{~m}$ isobath); the boulders are located between the seagrass beds and the fossil reef terrace relatively clear water with an average transparency of $6.2 \pm 2.1 \mathrm{~m}$. Highest mean water transparency was found near the mouth (8.1 $\pm 3.1 \mathrm{~m})$ and in the western part of the bay $(7.4 \pm 2.2 \mathrm{~m})$, whereas the lowest mean transparency was found in the eastern part (4.4 \pm $1.2 \mathrm{~m}$ ). The mean transparency on the reef just outside the bay measured $17.5 \pm 4.6 \mathrm{~m}$. The bottom in the eastern part of the bay is dominated by fine sediment areas, whereas in the western part it is largely composed of coarse sediment (Kuenen \& Debrot 1995).

A pre-study survey in the Spanish Water Bay revealed 6 main biotopes. These are the mangroves, seagrass beds, algal beds, channel, notches in fossil reef rock, and fossil reef boulders (Fig. 1). Data were collected in each of these biotopes, and on the coral reef along the coast of the island.
Table 1. Means and variation of environmental variables and habitat structure of mangroves and seagrass beds of the 12 study sites in the bay

\begin{tabular}{|lcc|}
\hline & Mean (SD) & Range \\
\hline Environmental variables & & \\
Water transparency $(\mathrm{m})$ & $6.2(2.1)$ & $2.4-11.0$ \\
Water temperature $\left({ }^{\circ} \mathrm{C}\right)$ & $28.3(0.2)$ & $27.0-31.4$ \\
Water salinity $(\%)$ & $35.4(0.2)$ & $34.3-36.3$ \\
Mangrove & & \\
Length along shoreline $(\mathrm{m})$ & $27(11)$ & $10-57$ \\
Width of mangrove fringe $(\mathrm{m})$ & $1.4(0.5)$ & $0.5-2.7$ \\
Water depth (m) & $0.8(0.2)$ & $0.4-1.1$ \\
Density of prop-roots $\left(\mathrm{m}^{-2}\right)$ & $7.4(5.9)$ & $2.0-34.6$ \\
Relative length of prop-roots $(\%)$ & $70.1(13.2)$ & $42.5-100.0$ \\
Light intensity between prop-roots $\left(\mu \mathrm{E} \mathrm{m}^{-2}\right)$ & $19.0(14.2)$ & $3.0-69.2$ \\
& & \\
Seagrass bed & $81(12)$ & $45-98$ \\
Seagrass cover $(\%)$ & $22(8)$ & $10-45$ \\
Height of seagrass $(\mathrm{cm})$ & $143(66)$ & $40-284$ \\
Density of seagrasses $\left(\mathrm{m}^{-2}\right)$ & \\
\hline
\end{tabular}


The red mangrove Rhizophora mangle dominates the shores of the bay and is most abundant in the eastern part of the bay. In other parts of the bay, the mangroves consist of isolated stands. The mangrove stands studied were on average $27 \mathrm{~m}$ long (i.e. distance along the shore) and $1.4 \mathrm{~m}$ wide (i.e. from the outer mangrove-fringe to the shoreline), and the water depth under the mangroves was on average $0.8 \mathrm{~m}$ (Table 1 ).

The shoreline areas of the shallow parts of the bay are dominated by turtle grass Thalassia testudinum. Seagrass is found at depths of $40 \mathrm{~cm}$ to $3 \mathrm{~m}$, but in the turbid areas of the bay it extends only to about $1.5 \mathrm{~m}$ depth. Mean seagrass cover was $81 \%$, and the seagrass leaves protruded on average $22 \mathrm{~cm}$ above the sediment (Table 1).

At depths of 2 to $6 \mathrm{~m}$, where light levels decrease, Thalassia testudinum is almost completely replaced by macroalgal species such as Halimeda opuntia, $H$. incrassata, Cladophora sp. and Caulerpa verticillata (Kuenen \& Debrot 1995). The density, areal cover and elevation of the algae are very low, however. Hence, the algal beds are sparsely vegetated and provide little shelter for fish.

In the central parts of the bay, at about $6 \mathrm{~m}$ depth, the bottom abruptly turns into a deep channel with a steep slope and a high turbidity. The channel is 11 to $18 \mathrm{~m}$ deep, reaching its greatest depth near the entrance of the bay. On the slopes of the channel, some small and large boulders of fossil reef rock are found, mainly covered with filamentous algae. The soft bottom of the channel is almost completely devoid of vegetation.

The shore on the southern part of the bay largely consists of a fossil reef terrace (up to $3 \mathrm{~m}$ high) which partly extends into the water. At and under the water line, biochemical solution has formed notches in the fossil reef terrace (de Buisonjé \& Zonneveld 1960), approximately $0.5 \mathrm{~m}$ below the water level and cut about $0.8 \mathrm{~m}$ into the reef terrace. Because the notches are shaded by the reef terrace material above, they receive little ambient light and their rocky surface is only sparsely covered with small fleshy and filamentous algae. Small to medium-sized rocks are often located just in front of the notches.

Massive boulders which have broken off the fossil reef terrace and tumbled into the water, are regularly found at distances of 0.5 to $2 \mathrm{~m}$ in front of the reef terrace, often partly extending above the water level. The mean circumference of the selected boulders measured $7.7 \pm 3.1 \mathrm{~m}$, and the mean water depth was $0.6 \pm 0.2 \mathrm{~m}$. At the bottom/water interface, the boulders mostly contain shallow cracks and holes, measuring $0.13 \pm 0.09 \mathrm{~m}$ in height, and their full extent was along $30 \pm 26 \%$ of the total circumference of the boulder. The rocky surface of the boulders is mainly covered by small fleshy and filamentous algae.

The fringing coral reef extends along the entire southwestern coast of the island. From the shore, a submarine terrace gradually slopes to a 'drop-off' at approximately 7 to $11 \mathrm{~m}$ depth. At the drop-off, the reef slopes off steeply, sometimes interrupted by a small terrace at 50 to $60 \mathrm{~m}$, and ends in a sandy plain at 80 to $90 \mathrm{~m}$ (Bak 1975). For a detailed description of the reef structure and distribution of corals on the reefs of Curaçao see Bak (1975).

Study design. All questions asked in the present study could be answered with a single study design: densities and lengths of all fish species were determined during daytime in all the main biotopes of the Spanish Water Bay and on the fringing coral reef outside the bay, on a relatively wide spatial scale. Many fishes show diurnal changes in habitat utilisation, and data on the fish community structure in the different biotopes at night are presented in Nagelkerken et al. (2000a).

Twelve study sites were selected throughout the bay (Fig. 1). Not all of the 6 biotopes were present at each site (Table 2). On the fringing coral reef, 5 study sites were selected at increasing distances down-current of the bay $(0.0,0.5,3.1,6.6$, and $11.9 \mathrm{~km})$. In all of the bay biotopes and on the coral reef, 4 replicate transects were randomly selected at each study site. Because the algal beds and coral reefs were distributed over a relatively large depth range, transects were placed at several depths for a representative sample of the community structure. On the reef, at each study site, the 4 replicate transects were taken at each of 4 depths: 2 , 5,10 , and $15 \mathrm{~m}$ (total $=16$ replicates site ${ }^{-1}$ ). On the algal fields, the 4 replicate transects were taken close to shore at $2 \mathrm{~m}$ depth as well as in the deeper parts of the bay at $5 \mathrm{~m}$ depth (total $=8$ replicates site ${ }^{-1}$ ). The data of the different depth zones on the coral reef were

Table 2. Comparison of sampling intensity, depth and area between the 7 different biotopes. The algal bed and coral reef were censused at multiple depths

\begin{tabular}{|lccccccc|}
\hline & Mangrove & Seagrass bed & Algal bed & Channel & Notch & Boulder & Coral reef \\
\hline No. of sites & 12 & 11 & 10 & 4 & 7 & 6 & 5 \\
Total no. of transects & 129 & 131 & 89 & 32 & 48 & 44 & 108 \\
Mean water depth $(\mathrm{m})$ & 0.8 & 1.5 & 2,5 & 6 & 0.5 & 0.6 & $2,5,10,15$ \\
Mean transect area $\left(\mathrm{m}^{2}\right)$ & 38 & 150 & 150 & 75 & 19 & 4 & 150 \\
\hline
\end{tabular}


pooled in all analyses; this was also done for the algal beds at 2 and $5 \mathrm{~m}$ depth.

Observations in the transects were done by 3 different observers. This was repeated for each transect 3 times: once during December 1997 to March 1998 (in random order), and twice in August 1998. One of the surveys in August was done only for the mangroves and seagrass beds. At each site for each biotope and for each study period, the 4 replicate transects were averaged. These averages were used as replicates for the different analyses. Although the data were sampled in 2 different seasons, it was not intended for analysis of temporal variation. Instead, the effort was focussed on studying as many biotopes as possible on an wide spatial scale. Seasonal variation in density of abundant fishes in the bay was small, compared to the daily variation and the variation in densities between different sites. Large fluctuations in densities of fishes in the bay did not occur, since settlement of juveniles in the bay was either continuous, occurred regularly for small numbers of recruits, or was absent. A large recruitment wave was noticed only once during the entire study period for Ocyurus chrysurus and Lutjanus mahogoni. At settlement, densities of the fish species may increase enormously, but as a result of post-settlement mortality, densities will strongly decrease again after some weeks (Shulman \& Ogden 1987, authors' pers. obs.). Data of recruits in the single large recruitment event were therefore excluded to obtain a more representative data set.

The fish community was studied using visual censuses in belt transects. The advantages of this technique are that it is rapid, non-destructive, inexpensive, can be used for all selected biotopes of this study, the same areas can be resurveyed through time, and the results can be compared with many other studies (English et al. 1994). Disadvantages are the differences in accuracy in estimation of numbers and sizes by the observers, and fishes may be attracted or scared off by the observers (English et al. 1994). Mainly Sparisoma chrysopterum and $S$. rubripinne were easily scared off in the bay biotopes and their numbers may have been underestimated. At the boulders, some nocturnally active fish species hiding in the crevices may have been underestimated too.

Species identification and quantification of fishes were first thoroughly practised by the 3 observers. Because most fish remained more or less in the same area, the observer effect on estimates of fish abundance is expected to be relatively small in most bay biotopes. Estimation of fish abundance only presented some difficulty in the mangroves, because grunts and snappers continuously moved in between the proproots, and visibility was sometimes reduced as a result of shading by the mangrove canopy. However, after extensive practise, and with aid of a flashlight in dark mangrove areas, the censuses could be done with reasonable accuracy. Also on the coral reef, fish moved more from one place to another, and here the observers effect in estimation of fish abundance (especially parrotfishes) is thought to be much stronger than in the bay biotopes. Within-reef data (Fig. 8) were therefore taken by a single well-trained observer.

The transects on the seagrass beds, algal beds and coral reef measured $3 \times 50 \mathrm{~m}$. In the channel they measured $3 \times 25 \mathrm{~m}$ because of the smaller area of this biotope. Isolated stands of mangrove were selected and surveyed completely. The band of mangroves fringing the shoreline was narrow (up to a maximum of $2 \mathrm{~m}$ ), permitting a complete and accurate census. Isolated fossil reef boulders were also surveyed completely. The notches in the fossil reef rock are continuous and were studied at each site in four $25 \mathrm{~m}$ long sections. For all transects in the mangroves, notches, and boulders, the total transect area was estimated by measuring the width at intervals of $5 \mathrm{~m}$ (for the boulders at intervals of $1 \mathrm{~m}$ ) and multiplying the mean width by the total length of the transect.

The transects were marked by a fine rope, placed at least 30 min before the survey began in order to minimise disturbance effects. SCUBA-gear was used on the algal beds at the $5 \mathrm{~m}$ depth, in the channel and on the coral reef. Snorkeling gear was used during all other visual surveys. During each survey, individuals of all fish species were counted and the total length of each fish estimated in size classes of $2.5 \mathrm{~cm}$. At the start of the study, size estimation was thoroughly practised, and during the study this practice was regularly repeated.

The surveys included almost all species which were seen in the transects, with the exception of small or cryptic fish species such as gobies, blennies and cardinalfishes. Due to identification problems, Belonidae were grouped as 'needlefishes'. The slender mojarra Eucinostomus jonesi and the silver jenny E. gula could not be distinguished in the field and were pooled as 'mojarra spp.'. Another species of mojarra which could not be identified in the field, but which was distinguishable from the mojarra spp. was labelled as 'mojarra sp. 1'. For small species of the pelagic water column forming large schools, viz. silversides, scads, herrings and anchovies, only the presence was noted.

The structural complexity and several environmental variables were studied in more detail for the mangroves and seagrass beds (see Table 1). During the surveys, water temperature, salinity and transparency were measured at $1 \mathrm{~m}$ depth at weekly intervals at each site between 14:00 and 16:00 h. The water transparency was measured as the maximum horizontal distance underwater at which the black and white quarters of a Secchi disk could still be discerned separately. 
In addition, light intensity (PAR) was measured between the mangrove prop-roots using a LI-1000 Datalogger (Li-Cor) light-meter with a cosine LI-192SA underwater quantum sensor. In the mangroves, the total number of submerged prop-roots and their total length (i.e. from the water surface to the tip of the root) were determined at intervals of $5 \mathrm{~m}$ in sample areas of $1 \mathrm{~m}$ long and the full width of the mangrove fringe. The sizes of the sample areas were measured and the proproot abundance expressed as the mean density of prop-roots per $\mathrm{m}^{2}$. The total length of the submerged prop-roots was standardised for water depth in the mangroves and expressed as relative length (i.e. as percentage of the total water depth). The size of the mangrove stands was measured and expressed as length along the shoreline, and width of the mangrove fringe. In the seagrass beds, 2 quadrats of $50 \times 50 \mathrm{~cm}$ were randomly selected per transect. In each quadrat, the seagrass cover was measured and expressed as 'percent seagrass cover', the average height of the seagrass leaves above the sediment measured and expressed as 'height of seagrass', and the total number of seagrasses counted (i.e. individual plants) expressed as 'density of seagrasses per $\mathrm{m}^{2}$ '. Furthermore, the distance from each mangrove/seagrass site in the bay to the mouth of the bay was measured as the shortest route a fish could travel between those points.

The total number of individuals in the entire bay of all fish species and of nursery species was calculated for each biotope as an indication of which biotope quantitatively contributed most to the total fish abundance in the entire bay. To calculate the total number of individuals, for each biotope, their total surface area in the entire bay (i.e. not the transect areas) was multiplied by the mean fish density of all species and of nursery species, respectively (data from Fig. 2a). The total area of the seagrass beds $\left(418047 \mathrm{~m}^{2}\right)$ and algal beds $\left(2346616 \mathrm{~m}^{2}\right)$ was calculated from a map. The total area of the mangroves $\left(10458 \mathrm{~m}^{2}\right)$ and notches $\left(2959 \mathrm{~m}^{2}\right)$ was calculated by measuring their total length along the shoreline of the bay from a map, and by multiplying this with their mean width. For the channel $\left(68431 \mathrm{~m}^{2}\right)$ the total length in the central part of the bay and in the narrow entrance to the reef was calculated from a map, and multiplied with the width of the channel slope (approximately 7 and $14 \mathrm{~m}$, respectively). It should be noted here that the total number of individuals for the channel refers specifically to the steep slopes of the channel, and not to the flat muddy area at the bottom of the channel. The latter could not be censused as a result of poor visibility, and a rapid survey showed much lower fish densities than on the rocky slopes. For the boulders $\left(210 \mathrm{~m}^{2}\right)$, the total number of boulders was multiplied by their mean surface area underwater.
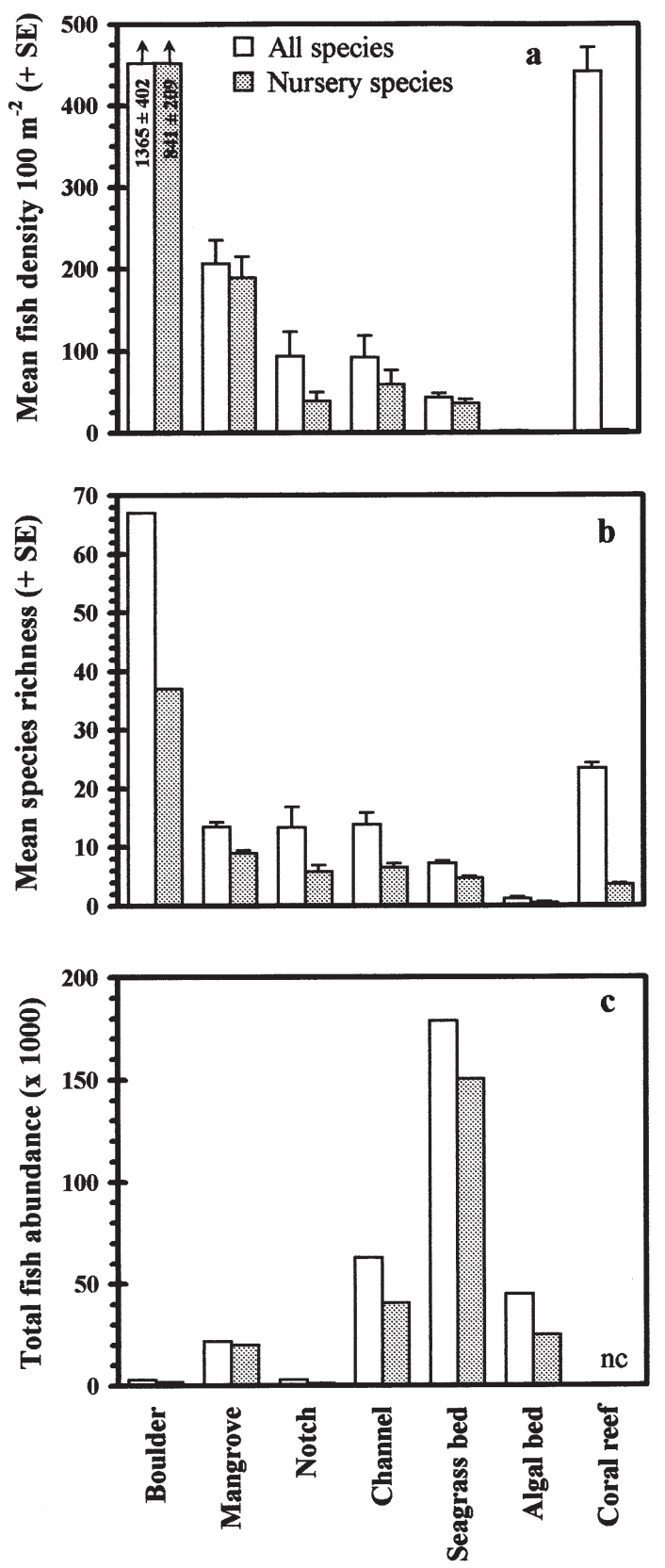

Fig. 2. (a) Mean fish density and (b) species richness in the 7 biotopes, and (c) estimated total number of fishes in the entire bay for each biotope. Comparison of species richness between small and large transects (see Table 2) is not valid as species richness increases with transect area. Transects in the boulders, mangroves, notches and channel were therefore pooled so as to form transects of approximately $150 \mathrm{~m}^{2}$ in order to enable comparison with the seagrass bed, algal bed and

coral reef (transect area $=150 \mathrm{~m}^{2}$ ). nc $=$ not computed

Statistical analysis. To compare fish densities, species richness and size distribution between the different biotopes, a 1-way ANOVA was used after data transformation (logarithmic or square root). Homogeneity of 
variances was tested with a Bartlett test, and normality was tested with a Kolmogorov-Smirnov 1-sample test (Sokal \& Rohlf 1995). Multiple comparison between the different biotopes was done using a Tukey HSD multiple comparison test. The same was done for comparison of fish densities between different reef sites.

For comparison of the community structure between the different bay biotopes, cluster analysis was used. Fish species densities in the different biotopes were first log-transformed, and cluster analysis was carried out using the programme CLUSTAN1C2 (Wishart 1978). The average-linkage method (Sokal \& Michener 1958) was used in combination with the Bray-Curtis coefficient.

To study the spatial distribution of fishes in the mangroves and the seagrass beds within the Spanish Water Bay, Principal component analysis (PCA) was used. PCA was carried out on log-transformed fish densities of the different study sites using the ordination programme Canoco 4.0 (ter Braak \& Smilauer 1998). Scaling was focussed on inter-species correlations, species scores were divided by the standard deviation, and the data were centred by species.

To test whether the spatial distribution of fishes in the mangroves and seagrass beds was related to environmental variables or habitat structure, an indirect gradient analysis within PCA was used (ter Braak \& Smilauer 1998), which calculated the correlations between the 4 PCA-axes and all measured environmental and habitat variables.

The importance of various environmental and habitat variables for the total fish density, for density of nursery, bay and reef species, and for species richness was examined with stepwise regression, with p-values to enter and to remove set at 0.15 , and the minimum tolerance for entry set at 0.1 (SYSTAT 1990). The predictor variables were checked for collinearity, and their relation with the dependent variables was calculated using multiple linear regression, if the assumptions of linear regression were met (Sokal \& Rohlf 1995).

\section{RESULTS}

\section{Biotope association and community structure}

During this study a total of 93311 fishes were counted, which in the bay represented 85 fish species belonging to 29 families (Table 3). Eucinostomus sp. 1, Stegastes leucostictus, S. variabilis, Sparisoma radians and Archosargus rhomboidalis were restricted to the bay. For the other species in the bay which were absent from the reef transects, it is known that they occur on the reef in low densities. Diodon holocanthus and the nursery species (see Fig. 5) Acanthurus chirurgus, Chaetodon capistratus, Gerres cinereus, Haemu- lon flavolineatum, H. sciurus, Lutjanus apodus, L. griseus and Scarus iserti occurred in all 7 biotopes (Table 3). Other fish species most frequently occurred in 2 or 3 different biotopes.

Mean fish densities were significantly higher compared to those in other biotopes, in the most rugose biotopes, the boulders and the coral reef (Fig. 2a, Table 4). The lowest fish density was encountered on the algal beds, with just 2 fish per $100 \mathrm{~m}^{2}$. The species richness showed a similar pattern, except that species richness in the mangroves was almost equal to that in the notches and channel (Fig. 2b). The total number of fishes (calculated by multiplying mean fish density with total surface area in the bay for each biotope), however, was highest on the seagrass beds and lowest at the boulders and notches (Fig. 2c).

The mangroves and seagrass beds were dominated by 2 to 3 fish species, and the other bay biotopes by 5 to 6 species (Table 5). Key species in most biotopes belonged to the Haemulidae and Lutjanidae (using these biotopes as nursery areas), but also to the Pomacentridae in the channel, notches and boulders (forming territories around the many rocks in these biotopes). Haemulon flavolineatum was the most common fish species, followed by Scarus iserti. Most fish species that were abundant in the bay showed low densities on the coral reef.

The fish species in the bay could be divided into 3 groups (see Table 3): (1) 'nursery species': reef fishes of which the juveniles use the bay as a nursery; (2) 'bay species': fish species which are relatively abundant in the bay and not present or occurring in low abundances on the coral reef; and (3) 'reef species': the remaining reef fishes of which all life stages are normally found on the coral reef. In most bay biotopes, the nursery species accounted for the majority of the total fish abundance (Fig. 3), especially in the mangroves and seagrass beds. The bay species were most abundant in the notches and algal beds, and the reef fish species in the channel, boulders and notches, all of which are rocky biotopes like the coral reef.

Cluster analysis based on mean fish species densities revealed 3 main clusters (Fig. 4): (1) the algal bed in the bay, which contained very few fishes; (2) the shallow-water biotopes in the bay, viz. mangrove, notch, seagrass bed, and boulder; and (3) the deeper biotopes, viz. channel and coral reef. The lowest dissimilarity was found between the fish community of the mangroves, notches, and seagrass beds.

\section{Nursery function}

Most fishes observed in the bay were juveniles and belonged to the nursery species group. In the algal 


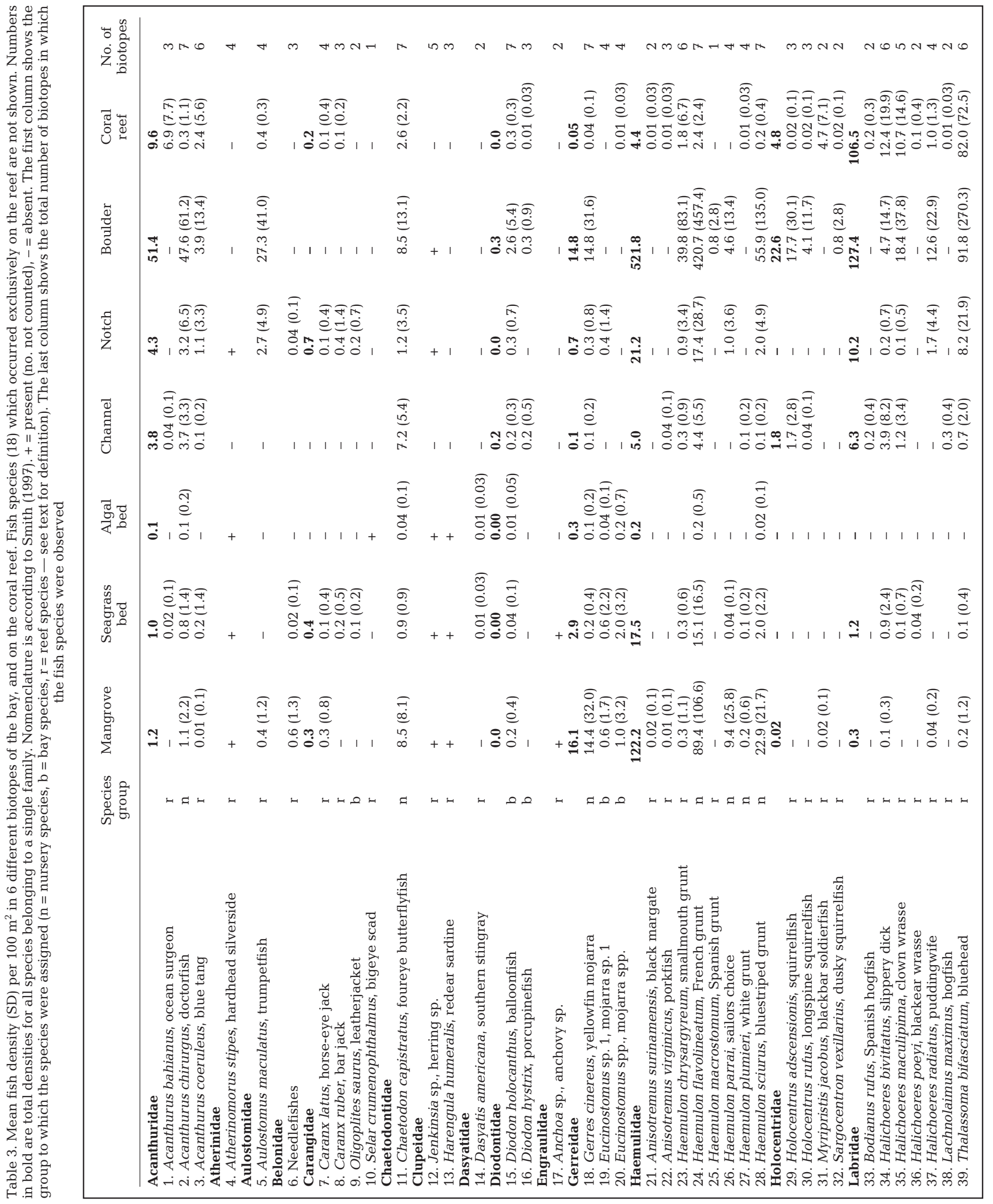


$\ln M \omega \rightarrow 0$ ง $)$ N $m$ m m $m 0 m+4$

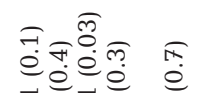

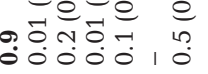

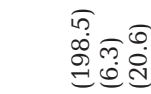

i.

क

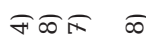

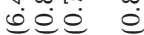
ก

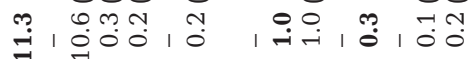

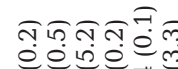

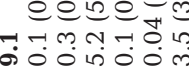

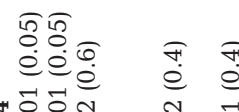

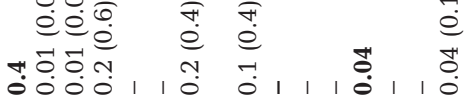

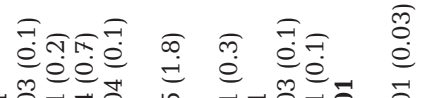

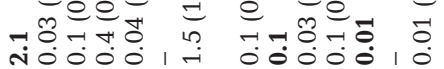

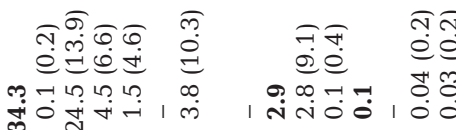

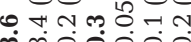

అ๑

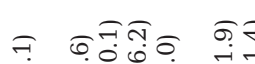

$\stackrel{0}{0} \dot{0} \dot{0} \dot{0} \dot{0}$

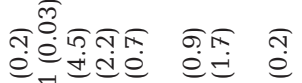

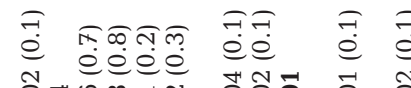

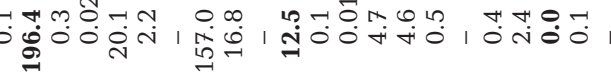

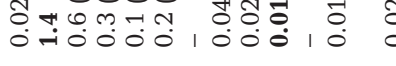

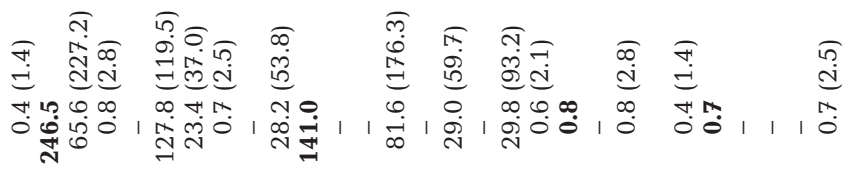

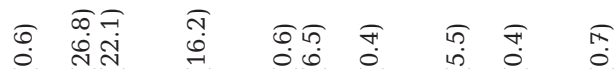

,

ee 0 b

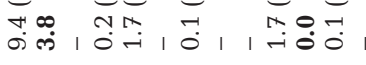

ळm

กับ

으

간

สิ

0 i 0

تِ

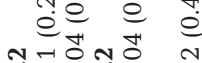
สฺุ

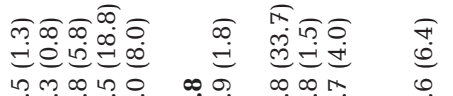

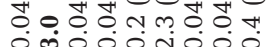

क.

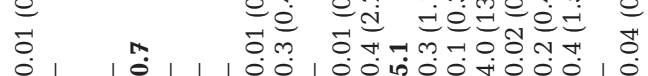

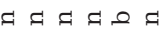

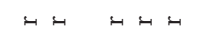

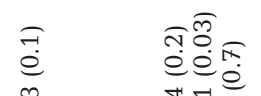

$\stackrel{m}{0}$ ก

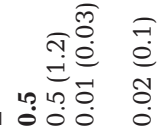

궁 สำ ำ 
Table 4. Tukey HSD multiple comparison between biotopes for fish density of all species (upper right part) and of nursery species (lower left part). Fish densities on transects were averaged per site and compared using a 1-way ANOVA

\begin{tabular}{|c|c|c|c|c|c|c|c|}
\hline Nursery species & Boulder & Mangrove & Notch & $\begin{array}{l}\text { All species } \\
\text { Channel }\end{array}$ & Seagrass bed & Algal bed & Coral reef \\
\hline Boulder & - & 0.000 & 0.000 & 0.000 & 0.000 & 0.000 & 0.126 \\
\hline Mangrove & 0.000 & - & 0.007 & 0.368 & 0.000 & 0.000 & 0.000 \\
\hline Notch & 0.000 & 0.000 & - & 0.992 & 0.458 & 0.000 & 0.000 \\
\hline Channel & 0.000 & 0.021 & 0.535 & - & 0.214 & 0.000 & 0.000 \\
\hline Seagrass bed & 0.000 & 0.000 & 1.000 & 0.497 & - & 0.000 & 0.000 \\
\hline Algal bed & 0.000 & 0.000 & 0.000 & 0.000 & 0.000 & - & 0.000 \\
\hline Coral reef & 0.000 & 0.000 & 0.000 & 0.000 & 0.000 & 0.053 & - \\
\hline
\end{tabular}

Table 5. Relative abundance (\%) of the principal fish species of each bay biotope, and their abundance on the coral reef

\begin{tabular}{|c|c|c|c|c|c|c|c|}
\hline & Mangrove & Seagrass bed & Algal bed & Channel & Notch & Boulder & Coral reef \\
\hline Archosargus rhomboidalis & & & 23.7 & & & & 0.0 \\
\hline Chaetodon capistratus & & & & 7.8 & & & 0.6 \\
\hline Eucinostomus spp. & & & 9.5 & & & & 0.0 \\
\hline Haemulon flavolineatum & 43.3 & 35.3 & 10.0 & 4.8 & 18.6 & 30.8 & 0.5 \\
\hline Haemulon sciurus & 11.1 & & & & & & 0.0 \\
\hline Lutjanus apodus & 11.9 & & & & 11.3 & 12.3 & 0.1 \\
\hline Lutjanus griseus & & & 10.6 & 5.6 & & & 0.0 \\
\hline Ocyurus chrysurus & & & 10.3 & & & & 0.1 \\
\hline Stegastes dorsopunicans & & & & & 17.2 & 9.4 & 0.5 \\
\hline Stegastes leucostictus & & & & & 9.9 & & 0.0 \\
\hline Stegastes partitus & & & & 9.2 & & & 35.5 \\
\hline Stegastes variabilis & & & & & 10.0 & & 0.0 \\
\hline Scarus iserti & & 32.6 & 9.6 & 33.6 & & 6.0 & 1.1 \\
\hline Thalassoma bifasciatum & & & & & 8.8 & 6.7 & 18.6 \\
\hline Total & 66.3 & 68.0 & 73.5 & 61.1 & 75.9 & 65.1 & 57.0 \\
\hline
\end{tabular}

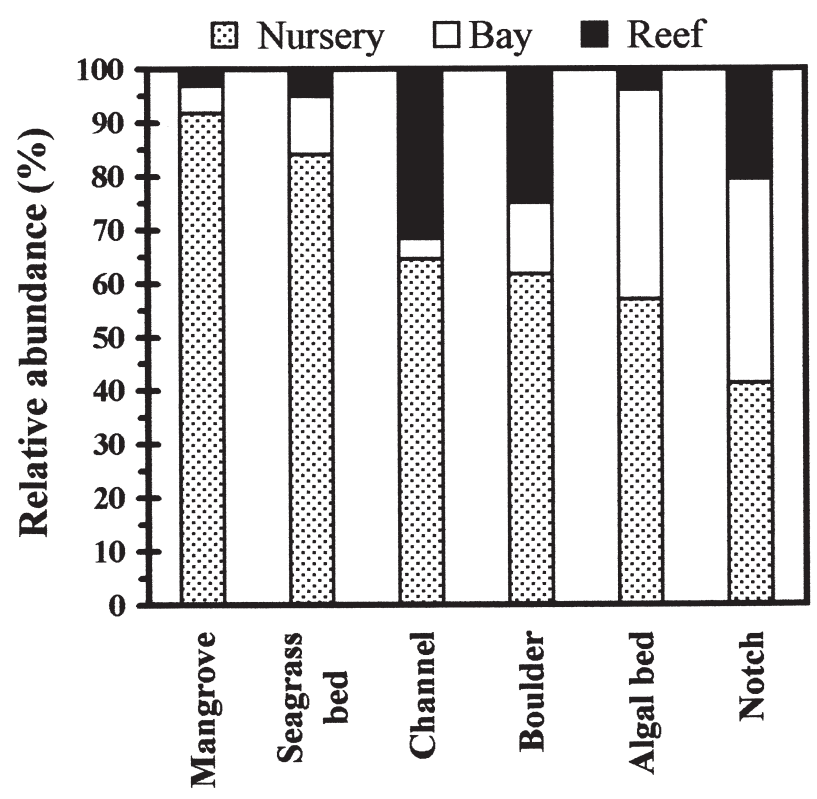

Fig. 3. Relative abundance of fish species groups in the 6 bay biotopes beds and channel, individuals of these species were somewhat larger than in the other bay biotopes. With the exception of Acanthurus chirurgus, the largest individuals of these species were mostly found on the coral reef (Table 6).

At least 17 fish species, found as adults on the reef, utilised the bay as a nursery. The importance of the nursery function of the bay biotopes for these species can be deduced from the high densities of the juveniles in the bay in contrast to the almost complete absence of juveniles on the coral reef (Fig. 5). The boulders and the mangroves contained the highest density and species richness of juvenile nursery species (Fig. 2a,b), but in terms of total number of individuals for the entire bay, the seagrass beds contained the most nursery fishes (Fig. 2c). Considering the ontogenetic utilisation of biotopes on species level, juveniles of nursery species were most abundant in the mangroves, and to a lesser degree in the seagrass beds, intermediate-sized fishes were often found in the channel, whereas large individuals were found on the coral reef (Fig. 5). For Gerres cinereus, Haemulon parrai, Lutjanus analis, L. griseus and Sparisoma chrysopterum no large individu- 


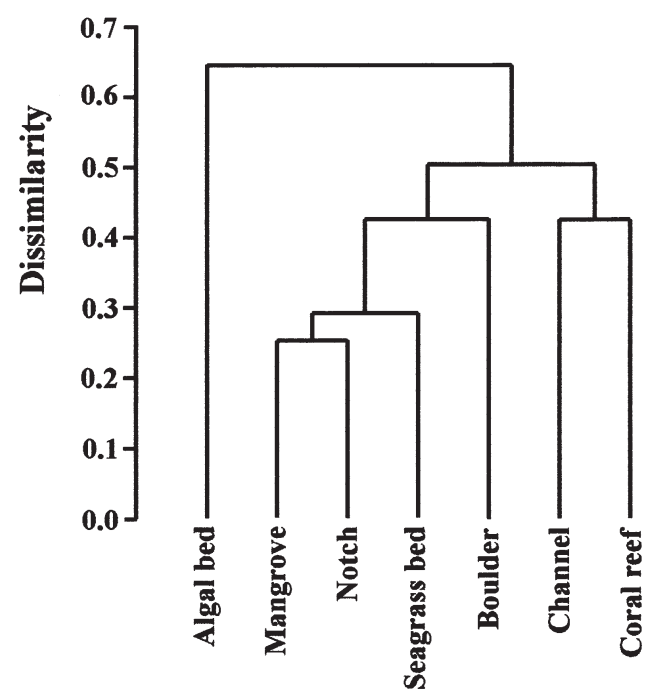

Fig. 4. Dendrogram of cluster analysis of fish species densities in the 7 biotopes

als were counted in the reef transects, although they were seen on the reef at other times. Juvenile parrotfishes (except Scarus guacamaia) were not only present in the mangroves and seagrass beds, but also in the channel.

\section{Spatial variation in fish density and size structure}

The fishes showed a spatial pattern in density distribution in the mangroves and seagrass beds. In the mangroves 3 clusters could be distinguished, which corresponded with 3 areas in the bay, following a gradient from the entrance to the far western end of the bay (Fig. 6a). Near the entrance, several species of parrotfishes, snappers, and damselfishes reached their highest density, e.g. Scarus iserti, Ocyurus chrysurus and Stegastes leucostictus. The typical reef fishes $\mathrm{Ha}-$ lichoeres bivittatus, Stegastes planifrons, and Thalassoma bifasciatum formed the second cluster and only occurred in the west-central part of the bay, at low densities. In the western part, Haemulon parrai and the bay species Eucinostomus spp., Gerres cinereus and Archosargus rhomboidalis reached their highest densities.

Also in the seagrass beds 3 clusters could be distinguished, but these followed a gradient from the entrance to the far eastern end of the bay (Fig. 6b). Near the entrance, Acanthurus chirurgus, Sparisoma radians, and 4 species of wrasses reached their highest density. The west-central part of the bay contained the majority of the fish species. In the eastern part, the bay species Archosargus rhomboidalis, Eucinostomus sp., and Gerres cinereus, 2 lutjanids, and Sphyraena barracuda reached their highest densities.

The dominant fishes in the mangroves and seagrass beds (see Table 5) showed no distinct spatial pattern in density distribution and occurred throughout the bay (Fig. 6). The most widespread fish species was Haemulon flavolineatum (occurring at all sites of the mangroves, seagrass beds, channel and boulders). Other widespread species were Lutjanus apodus (mangrove, notch, boulder), Chaetodon capistratus (mangrove, sea-

Table 6. Mean sizes of the nursery species in the 7 different biotopes. In each biotope, fishes were pooled at site level ( $>10$ fishes per site) for statistical comparison between bay biotopes and the coral reef (1-way ANOVA). *Insufficient replicates for comparison; these values were excluded from the statistical analysis and were calculated by pooling fishes of all sites. $-=$ fishes absent or abundance very low. na = not applicable

\begin{tabular}{|c|c|c|c|c|c|c|c|c|}
\hline & Mangrove & $\begin{array}{c}\text { Seagrass } \\
\text { bed }\end{array}$ & Notch & Boulder & $\begin{array}{l}\text { Algal } \\
\text { bed }\end{array}$ & Channel & $\begin{array}{l}\text { Coral } \\
\text { reef }\end{array}$ & $\begin{array}{c}\mathrm{p} \text {-values } \\
\text { lagoon vs reef }\end{array}$ \\
\hline Acanthurus chirurgus & 11.4 & 9.2 & 14.8 & 11.7 & 17.4 & 14.1 & 16.9 & $>0.067$ \\
\hline Chaetodon capistratus & 5.4 & 5.4 & $4.5^{*}$ & 4.3 & - & 5.8 & 7.6 & $<0.005$ \\
\hline Gerres cinereus & 7.0 & 11.3 & - & - & 15.3 & - & $18.4^{*}$ & na \\
\hline Haemulon flavolineatum & 8.4 & 7.2 & 6.2 & 7.8 & 9.0 & 10.8 & 14.0 & $<0.020$ \\
\hline Haemulon parrai & 5.7 & 7.8 & 3.8 & - & - & - & - & na \\
\hline Haemulon plumieri & 10.1 & 8.8 & - & - & - & - & - & na \\
\hline Haemulon sciurus & 10.2 & 10.1 & $15.8^{*}$ & 12.3 & - & - & 22.4 & $<0.002$ \\
\hline Lutjanus apodus & 11.8 & $10.5^{*}$ & 13.3 & 14.0 & - & - & 20.9 & $<0.001$ \\
\hline Lutjanus griseus & 11.5 & 13.2 & - & - & 16.6 & 15.2 & - & na \\
\hline Lutjanus mahogoni & 7.7 & 9.7 & - & 9.4 & - & - & $18.4^{*}$ & na \\
\hline Ocyurus chrysurus & 9.8 & 8.4 & - & - & $10.7^{*}$ & 8.9 & 17.2 & $<0.018$ \\
\hline Scarus coeruleus & - & 12.2 & - & - & - & 14.7 & $17.8^{*}$ & na \\
\hline Scarus iserti & 5.6 & 6.8 & $3.8^{*}$ & $3.9^{*}$ & $9.2^{*}$ & 7.0 & 11.1 & $<0.001$ \\
\hline Scarus guacamaia & 10.1 & 14.6 & - & - & - & - & - & na \\
\hline Sparisoma chrysopterum & 10.1 & 9.3 & - & $13.0^{*}$ & - & 19.5 & 17.6 & $<0.015^{\mathrm{a}}$ \\
\hline Sphyraena barracuda & 14.0 & 18.4 & - & - & - & - & - & na \\
\hline
\end{tabular}


grass bed, channel), H. sciurus (mangrove, seagrass bed), Scarus iserti (seagrass bed, channel), and Ocyurus chrysurus (seagrass bed, channel).

The reef species group showed a strong decrease in density in all bay biotopes with increasing distance from the mouth of the bay (Fig. 7).

On the coral reef, 5 nursery species and 1 bay species showed a decrease in density with increasing distance down-current from the bay (Fig. 8). The difference in density between the reef area in front of the bay and the other reef areas was only significant, however, for Stegastes dorsopunicans, Acanthurus chirurgus and Ocyurus chrysurus ( $\mathrm{p}<0.027,1$-way ANOVA and Tukey HSD multiple comparison). The decrease in density was not observed for Haemulon flavolineatum, Scarus iserti and Chaetodon capistratus. For the other nursery species, insufficient replicates were available for statistical comparison.

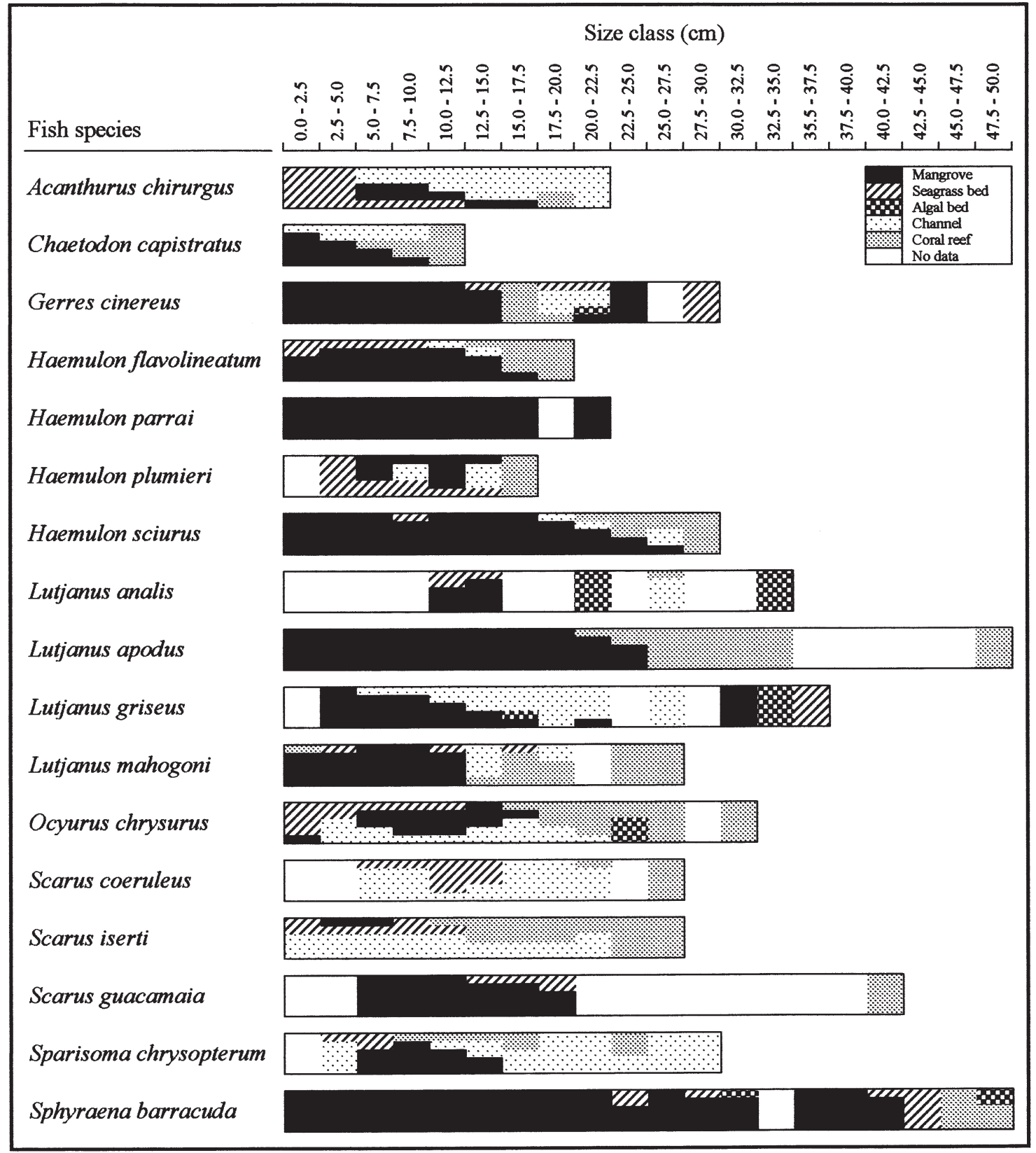

Fig. 5. Ontogenetic shifts in habitat association of the nursery species. For each size class of each fish species the relative abundance per biotope is shown as the percentage of the total abundance per size class (in all biotopes), rounded off to portions of $20 \%$. Boulders and notches are excluded as their areas are relatively small, causing high densities which skew the data. Furthermore, due to their low occurrence and relatively small area, they contribute less to the nursery function of the Spanish Water Bay in terms of total fish abundances, as compared to the other biotopes (see Fig. 2c) 

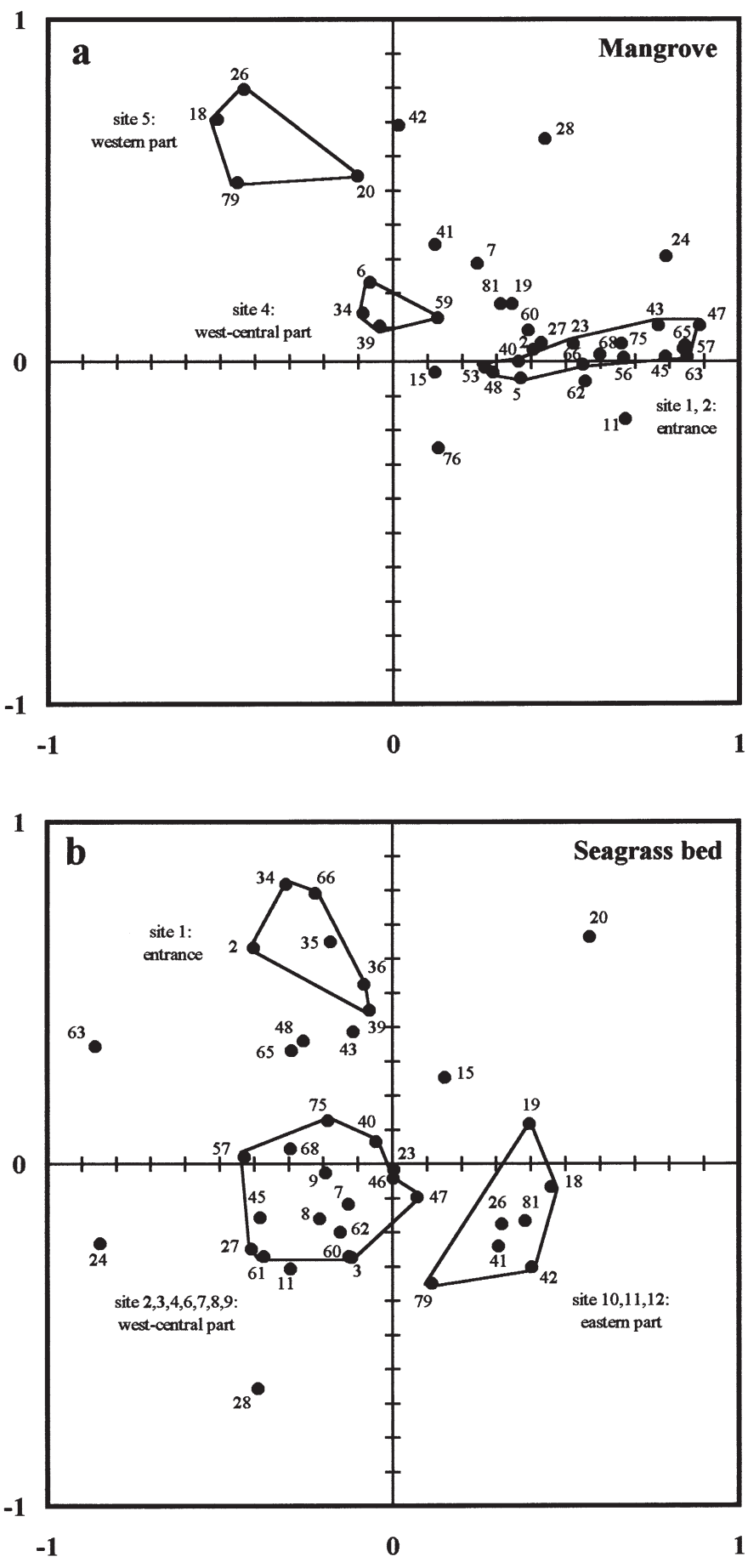

Fig. 6. Principal component analysis (PCA) of fish species densities at the different sites of (a) the mangroves, and (b) the seagrass beds. The horizontal axis represents the first PCA axis, the vertical axis represents the second PCA axis. The first 2 axes accounted for $56.5 \%$ in the mangroves and $54.7 \%$ in the seagrass beds of the total variance. Species clusters are enclosed by solid lines and are based on the sites in which a particular species is most abundant. The numbers refer to the fish species numbers in Table 3. Nine rare fish species are not plotted for the mangroves and the seagrass beds. See Fig. 1 for location of sites
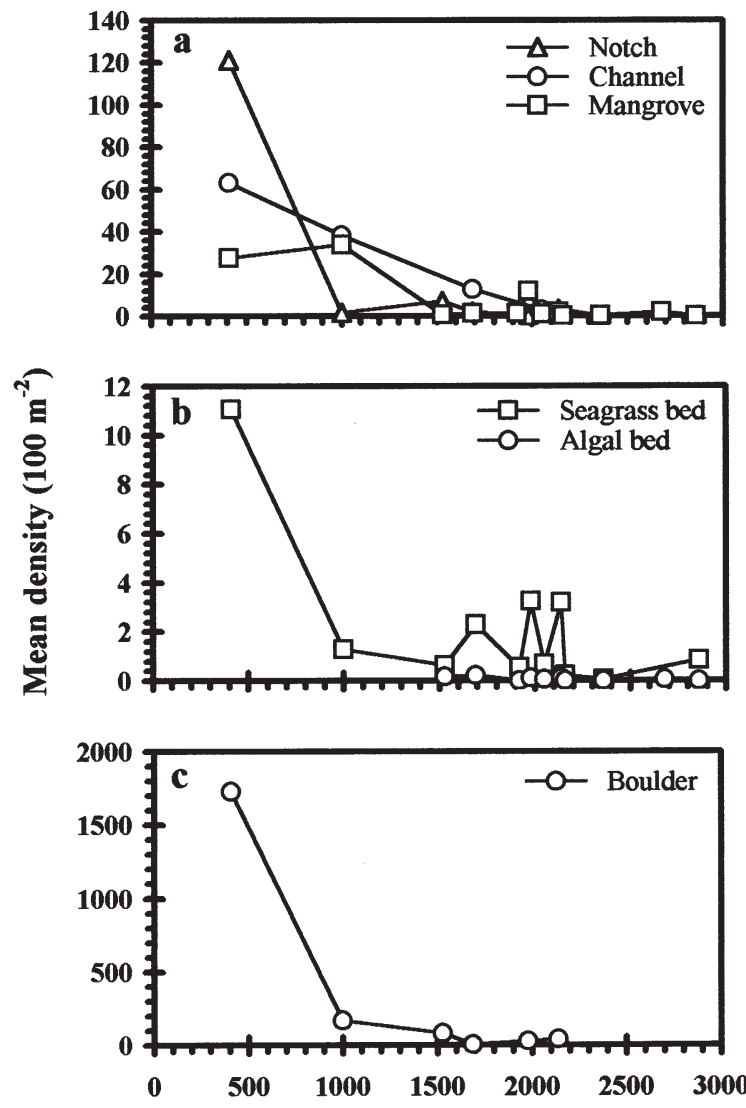

Distance to mouth (m)

Fig. 7. Mean density of the reef species group in the 6 different bay biotopes as a function of distance to the mouth of the bay

Three nursery and 1 bay species also showed a spatial pattern in size distribution between the seagrass beds. The nursery species showed a positive relation, whereas Archosargus rhomboidalis showed a negative relation with increasing distance from the bay mouth into the bay (Fig. 9).

\section{Associations with environmental variables, biotope structure and distance to the reef}

Several of the environmental and habitat variables in the bay were highly correlated with the first 2 (main) axes of the PCA for the mangroves and seagrass beds (Table 7). The 4 most important variables could be categorised for both biotopes as: (1) distance to the mouth of the bay, (2) water transparency, (3) amount of shelter (i.e. water depth in the mangroves and height of seagrass), and (4) structural complexity of the biotope (i.e. mangrove prop-root density and seagrass cover). In addition, water temperature was of importance on the seagrass beds. The total fish density, species rich- 


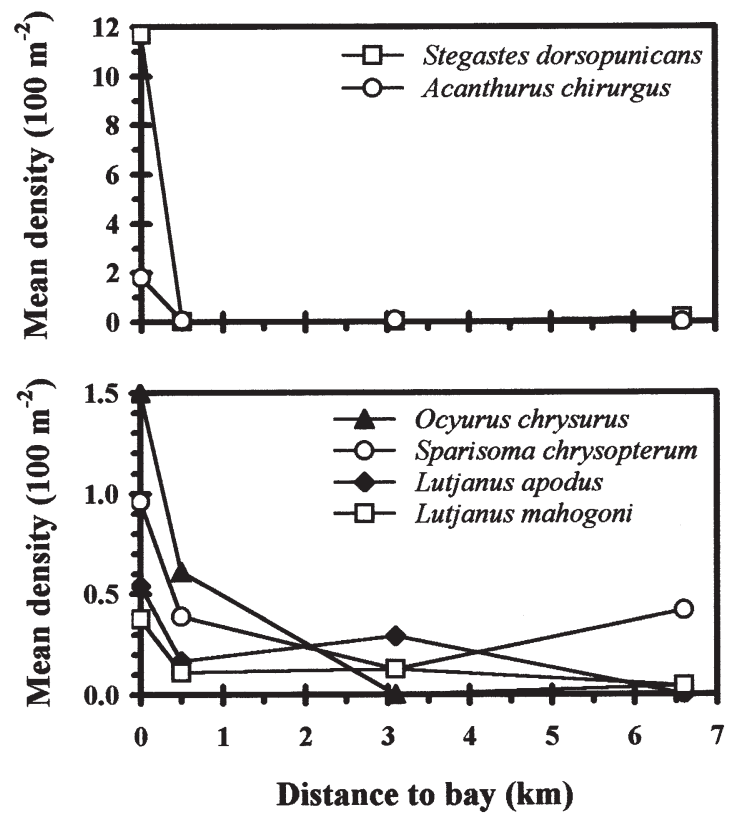

Fig. 8. Mean fish density of several nursery species and of Stegastes dorsopunicans on the coral reef as a function of distance to the mouth of the bay. All reef sites are located downcurrent of the bay, and in this area other lagoons are absent

ness and density of the different species groups in the 2 biotopes were related to a smaller set of variables, but these also belonged to the important variables as distinguished by PCA (Table 7). In all cases, the relation with distance to the mouth was negative, whereas the relation with water depth and transparency positive.

\section{DISCUSSION}

\section{Biotope association and community structure}

The Spanish Water Bay contained a high diversity of reef fish species. Of all species observed on the coral reef, over $75 \%$ were also found in the bay. Fish communities varied among the different bay biotopes, but some overlap was present, as also found by other investigators (Thayer et al. 1987, Sedberry \& Carter 1993, Acosta 1997, Nagelkerken et al. 2000b). In the present study the fish community structure of the notches, mangroves and seagrass beds were most closely related. The latter 2 biotopes were almost completely dominated by nursery species, which may explain their similarity. A separate cluster was found for the fish community of the channel and coral reef, which are both deep and rugose biotopes.

Factors which can explain differences in fish density between biotopes are structural complexity and amount of shelter they can offer to the fish (Luckhurst
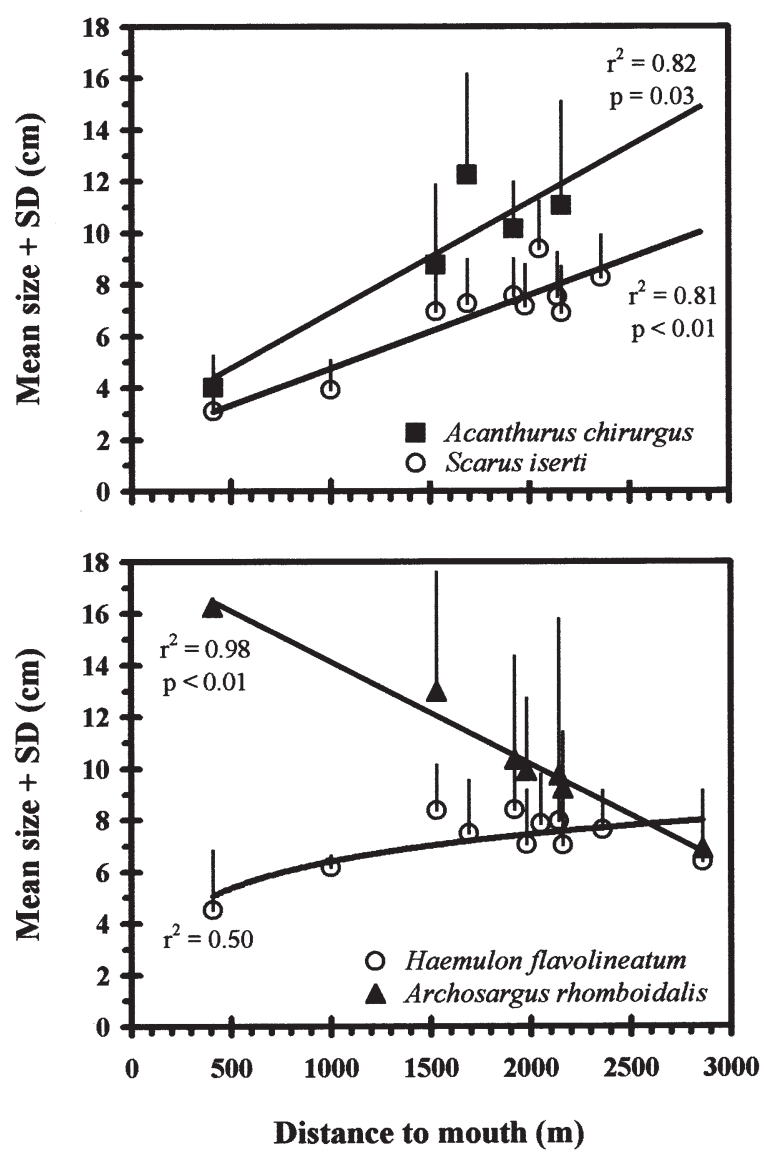

Fig. 9. Mean fish size on the seagrass beds in the bay as a function of distance from the mouth of the bay. Fishes were pooled at site level with a minimum of 10 fishes per site. Fitted (least squares) regression lines are shown together with their $\mathrm{r}^{2}$ and $\mathrm{p}$-values. For Haemulon flavolineatum a logarithmic regression $[y=a \times \ln (x)+b]$ was used and no $p$-value could be calculated

\& Luckhurst 1978, Carpenter et al. 1981, Stoner 1983, Bell \& Westoby 1986). In the present study the fish density and species richness were highest at the structurally complex boulders and coral reef, intermediate in the mangroves, notches, channel and seagrass beds, and lowest in the algal beds which provide very little shelter.

\section{Nursery function}

The Spanish Water Bay serves as an important nursery for at least 17 coral reef fish species, most of which are of commercial value to the reef fisheries. All biotopes of the bay, except the algal beds, were used as a nursery by juvenile reef fishes. This shows that not only mangroves and seagrass beds are important nursery areas, but shallow-water biotopes in general (Blaber \& Blaber 1980, Lenanton 1982, Nagelkerken et al. 2000b). Nevertheless, the importance of the nursery 
Table 7. Product-moment correlation coefficients of some important environmental variables with the 4 PCA axes of Fig. 6, and semi-partial correlation coefficients (the correlation between the unadjusted dependent variable with the respective variable after controlling for all independent variables in the equation) of predictor variables from stepwise multiple linear regression on density of all fishes and of the different species groups, and on species richness. ${ }^{*} p<0.05,{ }^{* *} p<0.01$. The + and - in front of the regression coefficients indicate whether the relation is positive or negative. $\mathrm{R}^{2}$ values are given for the final equations of multiple linear regression with the predictor variables

\begin{tabular}{|c|c|c|c|c|c|c|c|c|c|}
\hline & \multicolumn{4}{|c|}{ Principal component analysis } & \multicolumn{5}{|c|}{ Multiple linear regression } \\
\hline & Axis 1 & Axis 2 & Axis 3 & Axis 4 & $\begin{array}{c}\text { Total } \\
\text { density }\end{array}$ & $\begin{array}{l}\text { Species } \\
\text { richness }\end{array}$ & $\begin{array}{c}\text { Nursery } \\
\text { species }\end{array}$ & $\begin{array}{c}\text { Reef } \\
\text { species }\end{array}$ & $\begin{array}{c}\text { Bay } \\
\text { species }\end{array}$ \\
\hline \multicolumn{10}{|l|}{ Mangrove } \\
\hline Distance to mouth & $-0.72^{* *}$ & 0.15 & -0.24 & 0.14 & & $-0.51^{* *}$ & & $-0.82^{*}$ & \\
\hline Water depth & $0.45^{*}$ & -0.02 & 0.29 & -0.21 & $+0.76^{* *}$ & $+0.60^{* *}$ & & & $+0.65^{*}$ \\
\hline Density of prop-roots & -0.37 & $0.70^{* *}$ & 0.07 & 0.20 & & & & & \\
\hline Water transparency & -0.14 & $0.60^{*}$ & 0.14 & 0.10 & $+0.55^{*}$ & $+0.45^{* *}$ & & & \\
\hline Relative length of prop-roots & -0.28 & 0.23 & -0.29 & 0.18 & & & -0.54 & & \\
\hline Water temperature & -0.05 & 0.13 & -0.04 & -0.11 & & & & & \\
\hline \multirow[t]{2}{*}{ Light intensity between prop-roots } & -0.01 & 0.01 & -0.02 & 0.21 & & & & -0.36 & \\
\hline & \multicolumn{4}{|c|}{ Final equation: } & 1: $0.71^{* *}$ & $0.98^{* *}$ & 0.29 & $0.73^{* *}$ & $0.43^{*}$ \\
\hline \multicolumn{10}{|l|}{ Seagrass bed } \\
\hline Distance to mouth & $0.49^{*}$ & $-0.76^{* *}$ & -0.04 & -0.12 & -0.44 & -0.49 & & $-0.80^{* *}$ & \\
\hline Water transparency & $-0.49^{*}$ & $0.10^{*}$ & 0.30 & $0.20^{*}$ & +0.46 & & $+0.69^{*}$ & & \\
\hline Height of seagrass & -0.02 & $-0.46^{* *}$ & 0.13 & -0.12 & & & & & \\
\hline Water temperature & 0.05 & $0.11^{* *}$ & $0.49^{* *}$ & $-0.26^{*}$ & & $+0.57^{*}$ & & & \\
\hline Seagrass cover & -0.08 & 0.13 & 0.24 & $-0.44^{* *}$ & & & & & \\
\hline \multirow[t]{2}{*}{ Density of seagrasses } & 0.35 & -0.18 & 0.11 & -0.19 & & & & & \\
\hline & \multicolumn{4}{|c|}{ Final equation: } & : $\quad 0.60^{*}$ & $0.54^{*}$ & $0.47^{*}$ & $0.64^{* *}$ & \\
\hline
\end{tabular}

function differed significantly among biotopes. Boulders and mangroves harboured the highest densities of juvenile fish, presumably as a result of their high structural complexity which provides protection against predation. On the other hand, because they occurred in rather small and scattered patches, the boulders, and also the notches, contributed very little to the overall nursery function of the Spanish Water Bay. Instead, primarily the seagrass beds and secondarily the mangroves, channel and algal beds contained the most individuals as a result of their large surface area in the bay. This shows that the importance of a biotope as a nursery can not only be determined on basis of its fish densities, but on a combination of fish density and surface area.

The dependence of the nursery species on shallowwater biotopes may be very high and is possibly obligate for some species. Of the 17 nursery species, only juveniles of Haemulon flavolineatum and Scarus iserti were sometimes found on the coral reef. For the other 15 nursery species, juveniles were observed only in the various inland bays of the island containing mangroves and seagrass beds, and for some species additionally in shallow protected bays with a sand-rubble substrate (pers. obs.). Hence, shallow-water habitats, in particular bays containing mangroves and seagrass beds, probably provide a very large part of the nursery support for several economically important reef fish species in Curaçao. The pattern of decreasing fish densi- ties (i.e. nursery species) on the reef with distance down-current of the bay is consistent with the functioning of the bay as a source of recruits.

Several studies have shown that mangroves harbour higher densities of juvenile fish than adjacent biotopes such as seagrass beds and sand-rubble areas (Thayer et al. 1987, Robertson \& Blaber 1992, Sedberry \& Carter 1993). In the present study, the mangroves also harboured the highest fish densities of all bay biotopes studied, except the boulders, where densities of juveniles were about 4.5 times higher than in the mangroves.

Rugose habitats such as boulders, corals, or patch reefs appear to be important shelter sites for fishes in mangrove and seagrass dominated lagoons (Randall 1963, Ogden \& Ehrlich 1977, Kuenen \& Debrot 1995, pers. obs.). In St. Croix, Ogden \& Ehrlich (1977) and McFarland (1980) observed that postlarval grunts settle only briefly on the seagrass beds, and at lengths of about 2 to $12 \mathrm{~cm}$, all migrate to the patch reefs in the lagoon and form large schools. The relatively low abundance of corals and boulders in the Spanish Water Bay may explain why nursery species of 2 to $12 \mathrm{~cm}$ long can still be found abundantly in the mangroves and seagrass beds.

At some stage in their life cycle, the juveniles of many fish species become too large so that the bay biotopes are not longer suitable for protection, and the juveniles permanently migrate to the coral reef (Wein- 
stein \& Heck 1979, Shulman 1985, Rooker \& Dennis 1991, Nagelkerken et al. 2000b). In the present study, all nursery species showed this pattern. Some fishes, however, utilised the deep channel as a biotope for intermediate life-stages before migrating to the coral reef. The channel shows some resemblance to the coral reef habitat, but provides some advantages typical of lagoons and bays, such as lower densities and reduced foraging efficiency of predators (Blaber \& Blaber 1980, Robertson \& Blaber 1992).

\section{Spatial distribution of fishes and associated variables}

The axes of the PCA on the fish community of the mangroves and seagrass beds were highly correlated to a variety of environmental and habitat variables. Since the PCA axes describe the gradient in the distribution of species (the farther from the origin the more important), a correlation of a variable with the axes implies that for some species this variable is of greater importance than for others. Even though different species occurred in different densities in the 2 different biotopes, 4 types of variables could be identified in the mangroves and seagrass beds which were correlated to the species distribution (viz., distance to the mouth, water transparency, amount of shelter, and structural complexity). This suggests that in these 2 different biotopes, similar environmental and habitat variables may be determinants of the fish community structure.

The total fish density, density of the different species groups, and species richness in these bay biotopes were in most cases related to water depth, water transparency, and distance to the mouth. The positive relation with depth may be explained by the increase in shelter space. For the relation with transparency no explanation could be found. In other studies it has been hypothesised that in turbid water the foraging efficiency of fish predators decreases, resulting in higher abundances of prey species (Blaber \& Blaber 1980, Robertson \& Blaber 1992). In the present study, fish density was lowest in turbid water, whereas that of the piscivorous Sphyraena barracuda was highest. The negative relation with distance to the mouth was largely caused by the reef species group, which probably use the most seaward part of the bay as an extension of the adjacent reef. In contrast, several bay species (Archosargus rhomboidalis and mojarras) were most abundant in the most interior parts of the bay. The entire postlarval life cycle of these species, which are probably well adapted to the bay environment, is likely to occur within the bay. This may explain why these bay species are not abundant near the mouth of the bay, where the bay environment grades into a coral reef environment.
The juveniles of 3 nursery species showed an increase in mean size in the bay with increasing distance from the mouth (although maximum sizes in the bay were still much smaller than those of the adults on the coral reef). Other studies found large fishes on seagrass beds nearer to the coral reef as a result of diurnal feeding migrations from the reef to the seagrass beds (Ogden \& Ehrlich 1977, Ogden \& Zieman 1977, Baelde 1990), but such migrations were not evident in the Spanish Water Bay. The bay species Archosargus rhomboidalis showed an opposite pattern, with the smaller individuals being most abundant deep inside the bay. Archosargus rhomboidalis probably spawns in the bay (Houde \& Potthoff 1976), and the juveniles may only migrate toward the mouth when they grow larger. Baelde (1990) also observed that $A$. rhomboidalis (size range 9 to $24 \mathrm{~cm}$ ) were larger on seagrass beds near the reef than farther into the lagoon, although the smallest juveniles ( 0 to $4 \mathrm{~cm}$ ) were mainly present in the bay near the reef.

\section{CONCLUSIONS}

The main conclusions of the present study are: (1) fish communities varied among biotopes although some overlap was present, (2) all bay biotopes which provided shelter were used as nurseries by at least 17 reef fish species; the juveniles of these species were mostly found in the mangroves, some of the intermediate-sized fishes were found in the channel, and the larger individuals were found on the coral reef, (3) the spatial distribution of fishes was not homogeneous in the mangroves and seagrass beds and was largely correlated to distance to the mouth of the bay, water transparency, amount of shelter, and the structural complexity of the biotope.

Acknowledgements. This study was funded by World Wildlife Fund, The Netherlands (AVGN 97-1902), Prins Bernhard Fonds Nederlandse Antillen en Aruba (C-1748/97, P-263), and Carmabi Foundation-Curaçao Underwater Park. Additional funding was provided to M.D. and W.C.E.P.V. by Beijerinck-Popping Fonds and Stichting Nijmeegs Universitair Fonds (SNUF). E.C.d.l.M. was funded by the Netherlands Foundation for the Advancement for Tropical Research (WOTRO). We thank Dr M. de Kluijver for doing the CLUSTAN analysis, M. M. van Katwijk for help with the Canoco analyses and E. Kardinaal for the use of his map of Spanish Water Bay. Dr B. Winkel kindly made his pier and shed available at the Spanish Water Bay, and M. Vermeij loaned us his light meter. M. van Riel and F. Zimmerman provided logistic support in the field. We thank the staff and personnel of the Carmabi Foundation for their cooperation. We are indebted to Prof. P. H. Nienhuis, Dr A. O. Debrot and 4 anonymous reviewers for their comments and suggestions on the manuscript. 


\section{LITERATURE CITED}

Acosta A (1997) Use of multi-mesh gillnets and trammel nets to estimate fish species composition in coral reef and mangroves in the southwest coast of Puerto Rico. Caribb J Sci 33:45-57

Appeldoorn RS, Recksiek CW, Hill RL, Pagan FE, Dennis GD (1997) Marine protected areas and reef fish movements: the role of habitat in controlling ontogenetic migration. Proc 8th Int Coral Reef Symp 2:1917-1922

Baelde P (1990) Differences in the structures of fish assemblages in Thalassia testudinum beds in Guadeloupe, French West Indies, and their ecological significance. Mar Biol 105: 163-173

Bak RPM (1975) Ecological aspects of the distribution of reef corals in the Netherlands Antilles. Bijdr Dierkd 45:181-190

Bell JD, Westoby M (1986) Abundance of macrofauna in dense seagrass is due to habitat preference, not predation. Oecologia 68:205-209

Blaber SJM, Blaber TG (1980) Factors affecting the distribution of juvenile estuarine and inshore fish. J Fish Biol 17:143-162

Carpenter KE, Miclat RI, Albaladejo VD, Corpuz VT (1981) The influence of substrate structure on the local abundance and diversity of Philippine reef fishes. Proc 4th Int Coral Reef Symp 2:497-502

Carr WES, Adams CA (1973) Food habits of juvenile marine fishes occupying seagrass beds in the estuarine zone near Crystal River, Florida. Trans Am Fish Soc 102:511-540

de Buisonjé PH, Zonneveld JIS (1960) De kustvormen van Curaçao, Aruba en Bonaire. Nat Wet Werkgroep NA

de Haan D, Zaneveld JS (1959) Some notes on tides in Annabaai harbour, Curaçao, Netherlands Antilles. Bull Mar Sci Gulf Caribb 9:224-236

English S, Wilkinson C, Baker V (1994) Survey manual for tropical marine resources. ASEAN-Australia marine science project: living coastal resources. Aust Inst Mar Sci, Townsville, p 68-80

Heald EJ, Odum WE (1970) The contribution of mangrove swamps to Florida fisheries. Proc Gulf Caribb Fish Inst 22: 130-135

Houde ED, Potthoff T (1976) Egg and larval development of the Sea bream Archosargus rhomboidalis (Linnaeus): Pisces, Sparidae. Bull Mar Sci 26:506-529

Kuenen MMCE, Debrot AO (1995) A quantitative study of the seagrass and algal meadows of the Spaanse Water, Curaçao, The Netherlands Antilles. Aquat Bot 51:291-310

Lenanton RCJ (1982) Alternative non-estuarine nursery habitats for some commercially and recreationally important fish species of southwestern Australia. Aust J Mar Freshw Res 33:881-900

Luckhurst BE, Luckhurst K (1978) Analysis of the influence of substrate variables on coral reef fish communities. Mar Biol 49:317-323

McFarland WN (1980) Observations on recruitment in haemulid fishes. Proc Gulf Caribb Fish Inst 32:132-138

Nagelkerken I, Dorenbosch M, Verberk WCEP, Cocheret de la Morinière E, van der Velde G (2000a) Day-night shifts of fishes between shallow-water biotopes of a Caribbean bay, with emphasis on the nocturnal feeding of Haemulidae and Lutjanidae. Mar Ecol Prog Ser 194:55-64

Nagelkerken I, van der Velde G, Gorissen MW, Meijer GJ, van 't Hof T, den Hartog C (2000b) Importance of mangroves, seagrass beds and the shallow coral reef as a nursery for important coral reef fishes, using a visual census technique. Estuar Coast Shelf Sci 50:(in press)

Odum WE, Heald EJ (1972) Trophic analyses of an estuarine mangrove community. Bull Mar Sci 22:671-738
Ogden JC, Ehrlich PR (1977) The behavior of heterotypic resting schools of juvenile grunts (Pomadasyidae). Mar Biol 42:273-280

Ogden JC, Gladfelter EH (eds) (1983) Coral reefs, seagrass beds, and mangroves: their interaction in the coastal zones of the Caribbean. UNESCO Rep Mar Sci 23

Ogden JC, Zieman JC (1977) Ecological aspects of coral reefseagrass bed contacts in the Caribbean. Proc 3rd Int Coral Reef Symp 1:377-382

Parrish JD (1989) Fish communities of interacting shallowwater habitats in tropical oceanic regions. Mar Ecol Prog Ser 58:143-160

Perret WS, Caillouet CW (1974) Abundance and size of fishes taken by trawling in Vermilion Bay, Louisiana. Bull Mar Sci 24:52-75

Pollard DA (1984) A review of ecological studies on seagrassfish communities, with particular reference to recent studies in Australia. Aquat Bot 18:3-42

Randall JE (1963) An analysis of the fish populations of artificial and natural reefs in the virgin islands. Caribb J Sci 3: $31-46$

Robblee MB, Zieman JC (1984) Diel variation in the fish fauna of a tropical seagrass feeding ground. Bull Mar Sci 34: $335-345$

Robertson AI, Blaber SJM (1992) Plankton, epibenthos and fish communities. In: Robertson AI, Alongi DM (eds) Tropical mangrove ecosystems. Coast Estuar Stud 41:173-224

Rooker JR, Dennis GD (1991) Diel, lunar and seasonal changes in a mangrove fish assemblage off southwestern Puerto Rico. Bull Mar Sci 49:684-698

Rozas LP, Minello TJ (1998) Nekton use of salt marsh, seagrass, and nonvegetated habitats in a south Texas (USA) estuary. Bull Mar Sci 63:481-501

Sedberry GR, Carter J (1993) The fish community of a shallow tropical lagoon in Belize, Central America. Estuaries 16: $198-215$

Shulman MJ (1985) Recruitment of coral reef fishes: effects of distribution of predators and shelter. Ecology 66: 1056-1066

Shulman MJ, Ogden JC (1987) What controls tropical reef fish populations: recruitment or benthic mortality? An example in the Caribbean reef fish Haemulon flavolineatum. Mar Ecol Prog Ser 39:233-242

Smith CL (1997) National Audubon Society field guide to tropical marine fishes of the Caribbean, the Gulf of Mexico, Florida, the Bahamas, and Bermuda. AA Knopf, New York

Sogard SM, Powell GVN, Holmquist JG (1987) Epibenthic fish communities on Florida Bay banks: relations with physical parameters and seagrass cover. Mar Ecol Prog Ser 40:25-39

Sokal RR, Michener CD (1958) A statistical method for evaluating systematic relationships. Kansas Univ Sci Bull 38: 1409-1438

Sokal RR, Rohlf FJ (1995) Biometry, 3rd edn. WH Freeman and Company, New York

Springer VG, McErlean AJ (1962) Seasonality of fishes on a south Florida shore. Bull Mar Sci Gulf Caribb 12:39-60

Stoner AW (1983) Distribution of fishes in seagrass meadows: role of macrophyte biomass and species composition. Fish Bull 81:837-846

Stoner AW (1986) Community structure of the demersal fish species of Laguna Joyuda, Puerto Rico. Estuaries 9:142-152

SYSTAT (1990) SYSTAT: Statistics, Version 5.04. SYSTAT, Inc, Evanston, IL

ter Braak CJF, Smilauer P (1998) Reference manual and user's guide to Canoco for Windows: software for canonical 
community ordination (version 4). Microcomputer Power, Ithaca, NY

Thayer GW, Colby DR, Hettler WF (1987) Utilization of the red mangrove prop root habitat by fishes in south Florida. Mar Ecol Prog Ser 35:25-38

van der Velde G, Gorissen MW, den Hartog C, van 't Hof T, Meijer GJ (1992) Importance of the Lac-lagoon (Bonaire, Netherlands Antilles) for a selected number of reef fish species. Hydrobiologia 247:139-140

Weinstein MP, Heck KL (1979) Ichtyofauna of seagrass mead-

Editorial responsibility: Otto Kinne (Editor),

Oldendorf/Luhe, Germany ows along the Caribbean coast of Panamá and in the gulf of Mexico: composition, structure and community ecology. Mar Biol 50:97-107

Wishart D (1978) CLUSTAN user manual. Programme Library Unit, Edinburgh University, Edinburgh

Yáñez-Arancibia A, Lara-Dominguez AL, Rojas-Galaviz JL, Sánchez-Gil P, Day JW, Madden CJ (1988) Seasonal biomass and diversity of estuarine fishes coupled with tropical habitat heterogeneity (southern Gulf of Mexico). J Fish Biol 33(Suppl A):191-200

Submitted: July 19, 1999; Accepted: January 27, 2000 Proofs received from author(s): July 20, 2000 